International Journal of Child, Youth and Family Studies (2013) 2: 224-244

\title{
THE YOUTH VILLAGE: A MULTICULTURAL APPROACH TO RESIDENTIAL EDUCATION AND CARE FOR IMMIGRANT YOUTH IN ISRAEL
}

\section{Emmanuel Grupper}

\begin{abstract}
Migration, which has increased in the age of globalization, elicits a range of responses from the host countries, ranging from passive tolerance to active support of the newcomers. These responses affect many aspects of public life, most notably education, and the way immigrant youth are being either included or excluded. Residential care, which is known to be a powerful social instrument, is often used by societies for solving complex problems of children and young people. While many countries consider residential care an alternative of last resort, in Israel, these structural features of residential care institutions have been used for supporting young immigrants experiencing difficulties during the most crucial stage of the cross-cultural transition process. This paper presents the youth village, a unique Israeli residential educational model, highlighting the great potential of residential education and care programs for coping with the challenge of successfully integrating migrating youth. However, residential care methods and concepts are changing a lot and this influences how residential care programs are working with immigrant youth today.
\end{abstract}

Keywords: immigrant youth, multicultural, youth society, youth village, residential education, residential care, youth at risk, integration, inclusion

Emmanuel Grupper, Ph.D. is Dean, School of Education \& Society, Jerusalem Academic Center-Lander Institute, and senior lecturer, Department of Child and Youth Care, Beit Berl Academic College, P.O. Box 34353, Jerusalem 91343, Israel.

E-mail: Emmanuel.grupper@gmail.com 
International Journal of Child, Youth and Family Studies (2013) 2: 224-244

\section{Migrating populations}

Migration has increased worldwide since the late 1980s. The reasons people leave their country of birth are varied, as are the reasons they choose their host country, and these strongly affect cross-cultural transition (Gibson, 2001; Suarez-Orozco, 2007). Broadly speaking, migrants can be divided into displaced populations, labor migrants, and immigrants.

Displaced populations are, for the most part, refugees, people who decided to leave or were forced to do so because of war or political changes. Among recent examples are people who left the former Yugoslavia during the war of the 1990s, or those who escaped ongoing civil war in Sudan, the Republic of Congo, and the civil war that led to the genocide in Rwanda.

Labor migrants, who comprise the most frequent category, are people seeking better job opportunities with the hope of improving their quality of life and that of their families, and usually view the time spent out of their country as a temporary phase. Among contemporary examples are Turkish "guest workers” in Germany (JockenhovelSchiecke, 1994), and Moroccans and other Maghreb citizens to Western Europe (Fargues, 2011). When such migration is illegal, the problems are compounded, as they are when children are sent by their families to these host countries on their own as unaccompanied minors who later apply for refugee status. Labor migrants are not always willing to integrate culturally. They expect to gain concrete benefits from the host country, with the idea of returning to their native country after earning and saving enough money (de Vroome, Coenders, van Tubergen, \& Verkuyten, 2011).

Immigrants are individuals who plan their transition from one country to another, following a deliberate decision. Very often, they have a real desire to integrate in the new culture and make it their new homeland, as do immigrants to Canada, the United States, Australia, and Israel. Despite this desire, the adaptation process is accompanied by a great deal of ambivalence on the part of both the immigrants and the receiving society, as the immigrants are emotionally connected to their native culture and to their native language. At times, as in the case of French-speaking communities in Canada, the immigrants try to change the host culture to approximate their culture of origin (di Tomasso, 2012). The Israeli situation of Jewish immigration to the country is unique because of the traditional, age-old concept of the "ingathering of exiles in Zion" (Peres \& Lizika, 2008). Jews, who were exiled from the Land of Israel by the Romans in AD 70, always cultivated the desire to come back to their land, and in the beginning of the 20th century, the Zionist movement acted to build a new independent Jewish state. A linguistic manifestation of this ideal and ideology is the Hebrew term for immigration to Israel Aliyah (ascension), and an immigrant is an oleh (or olah in the case of a woman) ascender. However, the terminology is only one part of a complex reality. Thus, during the massive immigration of a million people from the Commonwealth of Independent States (CIS) to Israel in the 1990s, the immigrants chose to settle in segregated enclaves is some cities, as they had done in Brighton Beach in Brooklyn, New York in the 1980s (Al-Haj \& Leshem, 2000; Schmitter-Heisler, 2000). 
International Journal of Child, Youth and Family Studies (2013) 2: 224-244

\section{Host societies' attitudes toward migrant populations}

The adaptation process of migrant people is strongly influenced by the attitude of the host culture and the message it conveys to newcomers (Bhatnagar, 1981). Bhatnagar defines three main categories describing interaction modalities between host societies and immigrant groups, on a continuum from Assimilation to Integration (Figure 1).

Figure 1. Bhatnagar's Continuum

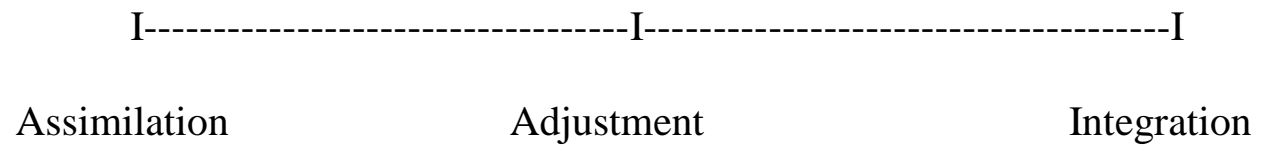

Assimilation refers to the host society's expectation that newcomers completely adopt the norms, language, traditions, and values of the host society, eventually becoming indistinguishable within the host society, forgoing their native language and culture (Greenman, 2011). Assimilation assigns the newcomers with complete responsibility for their adaptation. The host society adopts a passive role while the newcomers are expected to assimilate and "disappear in the crowd" of the host culture as rapidly as possible.

Adjustment refers to the process through which newcomers learn to live in a modicum of harmony with the new environment and their old culture, a co-existence of the old values and traditions with the new ones. The host society does not expect a complete disappearance of the culture of origin, but, like assimilation, adjustment is entirely assigned to the newcomers, provided it does not interfere with the prevailing culture. While this orientation allows individuals to achieve adjustment at a personal pace, it could bring about self-imposed segregation. Thus, migrant populations continue to live their traditional lives in their own areas, without making any effort to learn the language of the new society and to integrate in the new culture. Such immigrant enclaves can be found in the Netherlands where large populations of people from Suriname reside next to the big cities, in France where some suburbs are mainly populated by migrants from North African countries, and in the Turkish suburbs of Berlin. The adjustment model carries many problems and tensions between newcomers and veteran citizens living close to them, especially in poor neighborhoods.

Integration implies adjustment of both newcomers and natives. Although newcomers will have to do most of the adjusting, some changes on the part of the host culture will be required. Integration implies a multicultural society that considers the contribution of minority groups to be no less valuable than that of the majority members (Eisikovits, 1995a). Therefore, the norms and habits of a host society with an integration orientation cannot remain unchanged after the many new members it absorbed have added their imported cultural input. 
International Journal of Child, Youth and Family Studies (2013) 2: 224-244

Since the 1990s, Israeli immigration policies could serve as a good example for an integrative, culturally pluralistic model (Bardach, 2005; Eisikovits \& Beck, 1990; Yakhnich, 2008). The policy has been based on three principles: cultural pluralism in integration, utilizing the socializing force of informal settings, and social transaction. The first principle is the application of a culturally pluralistic model in integrating immigrant youth. An example, being first applied in residential care youth villages, is the celebration of Segd, a holiday celebrated by Ethiopian Jews only. This holiday, which was virtually unknown in Israel prior to the immigration from Ethiopia, had been first incorporated into the official school year (Shitrit, 2006) in residential programs where these young people were integrated. Later on it was adopted in all Israeli schools and finally, in 2008, a law was adopted by the Israeli Knesset (Israeli parliament) declaring the Segd an official holiday recognized by the state.

During the same period many cultural adaptations were made to incorporate the culture of immigrants from Russia: a Russian theatre was established and 13 new symphonic orchestras were created. Russian parents were not always satisfied with the level of science studies in Israeli schools and opened afternoon schools with pedagogical methods used in the CIS. Last but not least, in order to have more influence on decisionmaking processes they set up a political party which is represented in the Knesset by 12 representatives $-10 \%$ of all MPs (Feldman, 2007). All these changes could not have happened in Israel in the 1950s, when a strong assimilative orientation prevailed. The genuine will to integrate Jewish immigrants in an open and globalized world could be done successfully only within a pluralistic attitude that implies a readiness of the host culture to change during that process.

\section{Residential education and care as a preferred social instrument for absorbing migrant youth}

Residential education and care for educating children and youth at risk has been on the decline in many industrialized countries over recent years (Trede, 2008), one reason being the stigma attached to any kind of institutionalized setting. Today's orientation shows a preference for community-based programs, with residential care considered a last resort used only when all other interventions have failed (Frensch \& Cameron, 2002). In addition, the ever-increasing cost of treating a child in a residentialcare therapeutic program is encouraging policy-makers to look for less expensive solutions, even though their effectiveness has not always been proven (Eurochild, 2010; Grupper, 2002; Knorth, Harder, Zandberg, \& Kendrick, 2008).

Another principle applied in dealing with youthful immigrants' integration in Israel is using the high socializing potential of informal socialization agencies - youth movements (which are prevalent and popular) and youth villages, special communityoriented residential education and care programs. Empirical evidence has shown that youth villages have a great potential for enhancing immigrant youth's absorption and for facilitating their integration in the host society (Benbenisty \& Zeira, 2008; DavidsonArad, 2010; Kahane, 1986; Kahane \& Rapoport, 1990; Kashti, Grupper, \& Shlasky, 
International Journal of Child, Youth and Family Studies (2013) 2: 224-244

2008). The assumption is that "living in school” in group-care settings is profitable for all adolescents who take part in these social interactions, including native Israeli adolescents who join such programs because of family problems or a lack of resources in their local communities. These young people, whose schooling competencies are at an average level, or even less, could benefit from the interaction with new immigrants while introducing them, through daily contact, to their native-born peers' norms and behavior. These social-transactions are the third principle for the model of multicultural and heterogenic youth society in the youth villages.

Although Israel has also experienced some decrease in residential care (from 14\% in 1990 to $10 \%$ in 2008), it is still largely used for young people aged 12 to 18 from a wide range of cultural and social backgrounds. The underlying rationale for youth villages is based on Kahane and Rapoport's (1990) analysis of informal socialization agencies. Accordingly, opting for a structured organization of children's lives in residential education and care programs, allows these children to experience a kind of "moratorium". This is important for every adolescent (Erickson, 1955) but especially crucial for immigrant youth during their initial period in the new country. In Israel, about $15 \%$ of students aged 4 to 18 are immigrants. Of these, over $14 \%$ aged 12 to 18 are educated in a variety of residential schools of the youth village type (Ben Arie, Kosher, \& Cohen, 2009).

\section{Residential education and care in Israel}

The relative number of children and young people in residential education and care institutions in Israel is higher than in any other country, as many immigrant adolescents are placed in residential schools in order to complete their secondary education. These educational settings are particularly sensitive to the needs of multicultural youth populations. While numbers vary from one period to another, the general features have not changed significantly since the creation of the State of Israel in 1948.

The 586 residential programs in Israel are home to 67,240 children and youth aged 3 to 18, representing $4 \%$ of the overall population of children. In the 12 to 18 age group the rate was $14 \%$ in the 1990 s and $10 \%$ in the first years of the 21 st century (National Council for Children's Wellbeing, 2008). In a survey conducted in the last decade of the 20th century among 22 member countries of the Federation International de Communautes Educatives (FICE), Israel being one of them, no other country had such a high proportion of children in residential care programs (Gottesmann, 1991). A recent study encompassing children in alternative care in 32 European countries (Eurochild, 2010), reflects the same tendency. It can be roughly estimated that around 1\% of children are taken into extra-familial care across the European Union (EU). This proportion varies between countries - in Latvia 2.2\%, in Sweden $0.66 \%$, and in Romania $1.6 \%$ which is far less than the Israeli figures.

There are five categories of residential institutions in Israel - educational, rehabilitation, therapeutic, post-psychiatric, and crisis intervention shelters (Schmid, 
International Journal of Child, Youth and Family Studies (2013) 2: 224-244

2006). Educational residential programs are supervised by the Ministry of Education, and a state-recognized high school is usually an integral part of the facility. Rehabilitation, therapeutic, post-psychiatric facilities, and crisis intervention shelters are supervised by the Ministry of Social Welfare. For the most part, these institutions do not include a school on the premises, and the residents are placed in local schools in the nearby community.

The vast majority (85\%) of children and young people are placed in educational residential schools. This is a unique type of educational youth village, a care model that is neither a rehabilitation center nor a boarding school, but a place where young people are "living at school” (Arieli, Kashti, \& Shlasky, 1983). The youth village attempts to serve both educational needs and provide rehabilitation for those requiring it by creating a stimulating environment that can empower each young person (Grupper, 2008). In this kind of residential school, there is a tendency to bridge the gap and find appropriate educational and rehabilitative solutions for a large range of young people.

Among the young people who are being educated in youth villages are new immigrants who are in the midst of their cross-cultural transition process, children and youth who are in need because of family and social problems, young people seeking a second chance after having failed in local school, and young persons who have gone through an emotional crisis.

The most popular settings for immigrant youth are educational residential schools, which have a school on the premises. Most of the residents are adolescents in the 12- to 18-year-old age group, of whom two-thirds are immigrants. These immigrant adolescents include over 2,000 students who came to Israel on their own to study with the intention of remaining in the country, and for this population, the residential school must serve as a "first home" in Israel. These young people add to the diversity of the overall youth society in the residential schools, and contribute to making the life of all young people in such youth communities highly different from a classical treatment-oriented residential care institution.

Among the students in youth villages, some $10 \%$ to $15 \%$ required professional emotional guidance, care, or even therapy, which they received on an individual basis, while all other aspects of their life are lived as part of a completely normative environment. Table 1 presents the overall composition of the residential education and care field in Israel, including those for overseas students. 
International Journal of Child, Youth and Family Studies (2013) 2: 224-244

Table 1. Israeli children and adolescents in residential education and care programs (excluding disabled children placed in other types of residential care programs)

\begin{tabular}{|l|c|c|}
\hline Type of residential program & $\begin{array}{l}\text { Number of } \\
\text { establishments }\end{array}$ & $\begin{array}{l}\text { Number of children } \\
\text { in care }\end{array}$ \\
\hline & & \\
\hline Non-religious residential education and care & & \\
\hline Youth villages & 70 & 15,800 \\
\hline Youth groups in kibbutz & 7 & 600 \\
\hline Children's homes & 65 & 6,000 \\
\hline Maritime schools & 6 & 800 \\
\hline Residential schools focused on sports & 6 & 650 \\
\hline $\begin{array}{l}\text { Residential schools focused on arts or other } \\
\text { specific educational tracks }\end{array}$ & 27 & 1,000 \\
\hline & & \\
\hline Religious residential education and care & & 7,400 \\
\hline Religious youth villages & 28 & 180 \\
\hline Youth groups in religious kibbutz & 6 & 1,850 \\
\hline Religious children's homes & 18 & 14,900 \\
\hline High school (yeshiva) for boys & 158 & 7,360 \\
\hline High school (ulpana) for girls & 56 & 6,350 \\
\hline $\begin{array}{l}\text { Religious residential schools with specific } \\
\text { educational tracks }\end{array}$ & 26 & $\mathbf{6 7 , 2 4 0}$ \\
\hline & & 850 \\
\hline Other kinds of residential program & 5800 \\
\hline Youth protection residential programs & 39 & \\
\hline $\begin{array}{l}\text { Residential programs with special education } \\
\text { schools }\end{array}$ & 32 & \\
\hline Family home units & 58 & \\
\hline & & \\
\hline Total & & \\
\hline
\end{tabular}

(Source: National Council for Children’s Wellbeing, 2008)

\section{The reasons for high demand for residential education and care in Israel}

In 1953, the Knesset passed the Law for Public Education. In recognition of the various ethnic and religious groups, the law enables individuals to choose their preferred form of schooling for their children. The Jewish population has the choice of co-ed state schools, state-religious schools (some of which are co-ed, others separate for boys and girls, which add religious studies to the state-school curriculum), and ultra-orthodox (Haredi) schools, all of which are separate for boys and girls. In these schools, financed 
International Journal of Child, Youth and Family Studies (2013) 2: 224-244

and supervised by the Ministry of Education, the language of instruction is Hebrew. The Arab population has its own schools, also financed and supervised by the Ministry of Education, where the official language of instruction is Arabic. The focus of this paper is on immigrant youth. Therefore, the Arab population in Israel is beyond the scope of the present discussion.

In both the Jewish and Arab sectors there are a small number of private schools, but the majority of children attend state-funded public schools. Among religious schools, and particularly among the ultra-orthodox, schools are divided by sex. Girls who attend religious schools learn general studies and religious studies, while those for boys are mainly focused on religious studies. Many of the religious schools are residential schools, a fact which bears on the discussion of residential care in Israel.

In Israel, residential education and care is less stigmatized than elsewhere, and residential schools are perceived as normative and educative alternatives. All partners involved - practitioners, policy-makers, administrators, children, and parents - view the range of residential alternatives as a continuum, with the elite boarding schools on one end and the residential crisis intervention centers on the other. This means that there are multiple possibilities for children and young people to "move" along the continuum and choose, from among the different types of residential models, the one that best suits their needs at every particular stage of their education.

Figure 2. The Continuum of Residential Education and Care Models

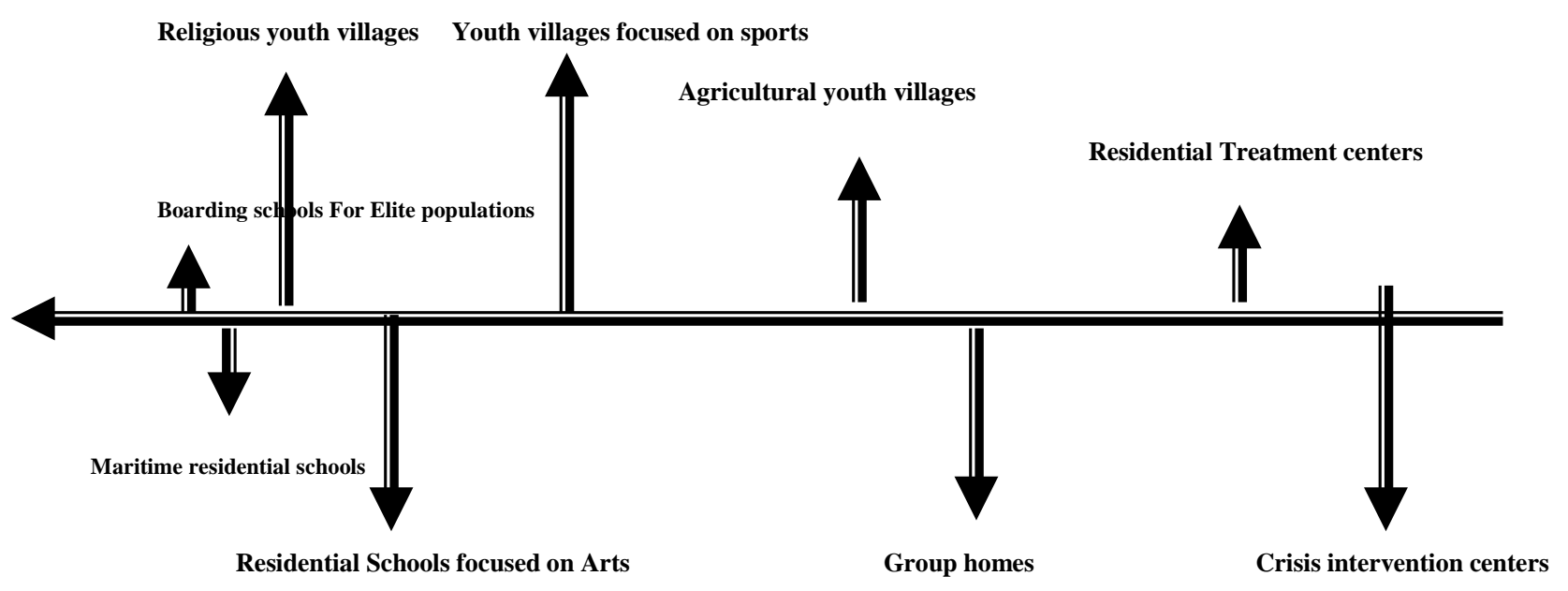

The Israeli youth village: An educational residential model

The prototype of the leading Israeli educational residential institution is the youth village. Like many other revolutionary movements (Bronfenbrenner, 1970), the Zionist movement, in its initial phase, largely used group-care methods in order to educate youth 
toward its new social challenges (Figure 3). This education began in the late 19th and early 20th centuries with Zionist youth movements in Europe, and these later formed the community model of the kibbutz (Kashti, 2000). The kibbutz movement, which represented a new way of voluntarily chosen community life, provided the model for the creation of youth villages, based on shared living of youth and adults in a small and integrated educative community (Grupper, 2008; Arieli \& Kashti, 1976).

\section{Figure 3. Israeli Youth Village Model}

\section{Boarding schools for elite children and youth}

\section{Populations}

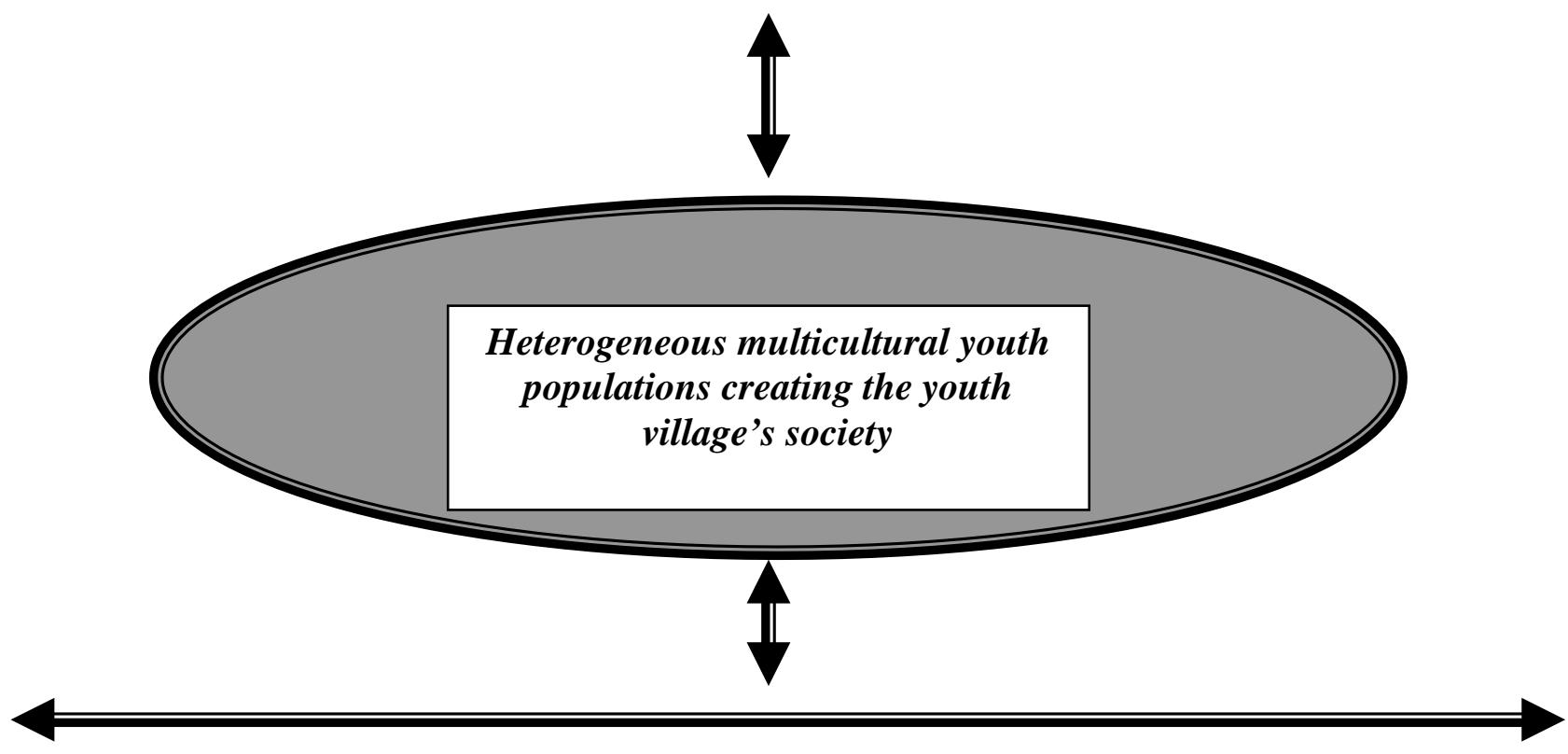

Residential treatment centers for populations of children and youth in high risk situations and in need of rehabilitation 
International Journal of Child, Youth and Family Studies (2013) 2: 224-244

Most countries have two distinct models of residential education and care settings for children and young people, rehabilitation schools and schools for the elite. The first focused on the rehabilitation needs of populations of children and young people who are at high risk, such as school dropouts, those excluded from mainstream schools, delinquent youth, and children and young people with problematic family backgrounds and severe emotional problems. The second are specialized educational residential schools that cater to elite groups of children and young people, for example, the public schools in the United Kingdom (Kahan, 1994). These are prestigious educational institutions with well-defined programs, aiming at maintaining the predominance of elite groups in society (Lambert, 1975). Such specialized boarding schools exist in many countries: maritime schools, military schools, preparatory programs for prestigious higher education establishments, religious boarding schools, etc. These two different types of residential education and care programs make use of the common structural features of residential programs that can offer a well-structured and relatively closed environment, which create the potential to rehabilitate and empower children and young people (Arieli \& Kashti, 1976; Eisikovits, 1995b, 2008; Grupper, 2008).

At the core of this residential model is a heterogeneous and multicultural composition of the youth community. The youth village maintains a balance between normative students who need residential care because they are immigrants in the midst of cultural transition, and Israeli-born students who need residential education and care because of family problems, and provides both groups with a real chance to enter the social mainstream. In residential schools where there is enough heterogeneity of the youth society, the ellipse is located in the middle of the diagram (Figure 3). In those youth villages where there is a preponderance of youth at high risk, the heterogeneity diminishes and the ellipse is directed toward the treatment-oriented residential care models. In these cases, the educative and open model has difficulties in producing social integration results. It is claimed (Kashti et al., 2008) that the current situation in Israel, when fewer immigrants are arriving in the country and the youth society of part of this network is losing its heterogeneity, might in the long run be harmful to the functioning of the youth villages.

The youth village model is based on the socializing power of a cohesive community, with kibbutz community life as its ideal. Bronferbrenner's (1979) ecological theory, according to which children's development is not influenced only by the microsystem, could serve to analyse and explain the elements of the youth village model. In addition to the micro-system, Bronferbrenner lists other influences, as a result of people acting in broader circles which he calls the meso-system and exo-system. Even more important are influences by persons acting on the macro-system level, and the development of a child is the end product of all these different activities. Indeed, in the youth village the entire environment participates in the educational process, including those who interact face-to-face with the child on the micro level and also those acting on the other ecological levels.

This ecological concept can be applied at different levels, in every youth village as an autonomous entity, and also at the youth village as part of a larger national network. 
International Journal of Child, Youth and Family Studies (2013) 2: 224-244

The Israeli residential education and care settings are organized in a relatively large network which allows each institution to act autonomously, while enabling the network as a whole to set general educational orientations and apply across-the-board policy changes. A current example of such policy change has been taking place since the early 2000s, with parental involvement increasing in residential schools or in more specialized residential care programs (Grupper \& Mero-Jaffe, 2008).

Historically, residential staff tried to minimize children's contact with their families (Gottesmann, 1988). It is now universally accepted that this approach is wrong and harmful for all children, most particularly for immigrant youth (Klap, 2008). Therefore, decision-makers, researchers, scholars, and people in the media, all acting at the macro-system level, have shaped public opinion and workers' attitudes toward accepting school-parent interaction. Program planners and policy-makers, staff training programs, supervisors, and program directors, all acting on the meso-systems and exosystems, are developing concrete programs that can be applied by direct-care staff in their daily work at the micro-system level. Consequently, parents are now invited to share activities with their children. Among these activities are dynamic joint child-parent weekly workshops, inviting parents to prepare a meal their child and his/her group, participating in joint children-parents summer camps, having "family days" in the residential school several times a year, inviting parents to celebrate festivities in the residential school - from their child's own birthday to celebration of national holidays. These activities, some initiated by local staff or directors, others by supervising agencies like the Ministry of Education, are successfully reshaping youth village norms and procedures, and creating a completely different ecological environment for children in residential education and care in Israel.

\section{Creating a sense of belonging to a community}

Young people and adults living together can create a united community. This, in a way, puts into action Jones et al.'s (1986) concept of quality residential care being defined as: "Living together as a profession”. In residential communities where children and adults live together, the prevailing atmosphere is of a group of people having common goals in living together, which is instrumental in avoiding the negative effects of a "total institution" (Goffman, 1962).

The fact that young people live together and are supervised 24 hours a day in a well-designed environment is a very powerful stimulation for them to achieve behavioral changes. This is especially true for detached youth. However, these behavioral changes are achieved through endless discussions and open negotiations between young people and staff members and by modeling on the part of the staff, not by authoritative discipline. This implies that the relationships between youth and adults are symmetric, rather than the kind of relationship developed in programs operating under the "medical model” (Anglin, 2002). This kind of environment is particularly important for migrant young people who are looking for clues to overcome their marginal status which is the starting point in their cross-cultural transitional process. 
International Journal of Child, Youth and Family Studies (2013) 2: 224-244

In order to enable every member of the community to feel at ease, the community is based on pluralistic and multicultural values. The youth population is composed of new immigrants from varied cultural backgrounds: Ethiopia, the CIS, Europe, North America, and Latin America. Other members of the community are Israeli-born adolescents who come from the geographical and socio-cultural periphery. Creating a sense of belonging (Brendtro, Brokenleg, \& Van Bockern, 1990) in such a community is possible only if staff members apply a true and genuine culturally pluralistic attitude, which can happen only if the prevailing atmosphere emphasizes the importance of every individual finding their place in such a community.

As an example, we can present the integration of Ethiopian youth in such youth communities. Many of these young people came to Israel in the 1980s without their parents, and the youth villages were, in many respects, their first home in Israel. In order to give them the feeling that they are fully accepted by the community, and enable them to feel the sense of belonging, some of their cultural traditions were incorporated by the community as a whole. In keeping with the idea that although youth villages are part of a network, each has the autonomy to seek ways to meet the needs of its residents, it is important to add that these changes were the initiative of creative youth villages' directors. These directors - who are educators and not solely administrators - felt that the young immigrants from Ethiopia did not feel themselves at home among their peers in the youth village. Therefore they looked for a substantive cultural element of the newcomers' culture such as celebrating holidays like the Segd, unknown to Jewish society until the arrival of Ethiopians to Israel (Shitrit, 2006) and make it a big event for the entire village population, youth and adults alike.

\section{Primacy of education over treatment}

The Israeli residential model is based on the principle of normalization, and the aim is to give the young person in the residential school the feeling of being in a "normal" educational setting. Thus, a normative school is a central part of the residential program and the educational success of every child is a primary target of the whole staff. This is not easily achieved. Diverse support systems, both during and after school hours, are used to help children succeed in their studies. Although the school is part of the mainstream secondary school system (and not part of the special education school system), it has to develop special tracks and methods. The residential school must also train its teaching and educational staff through in-service-training programs to deal with a wide variety of students, and enable every child to experience success. This objective, to help all youth villages' children to be successful in their studies, is supported by a systematic study about graduates of youth villages (Benbenisty \& Zeira, 2008; Zeira, 2009).

The kind of orientation that gives priority to the success of children in their schooling requires that in the everyday decision-making process, educational considerations be given priority over therapeutic considerations. Although the children often have special emotional needs and the interventions of social workers, psychologists, 
International Journal of Child, Youth and Family Studies (2013) 2: 224-244

or even psychiatrists are focused on these individual needs, they should not interfere with the overall atmosphere that deliberately emphasizes education over therapy.

\section{Empowerment of children and staff as a major challenge}

In order to realize the ambitious educational challenges presented here, every activity has to convey a message of empowerment. The staff must make every effort possible to ensure that children should experience success in whichever activity they are engaged, be it scholastic, sports, artistic endeavors, working on the farm, or vocational training. Special importance is attached to involving youth in self-governance activities in the various aspects of the residential school's daily life.

Empowerment of youth is also gained through their active enrolment in leadership activities through which they experience responsibility taking, and also the rewards of successfully accomplishing different kinds of social activities. These include volunteer work in neighboring communities such as helping elderly people, coaching young children, and performing in ceremonies and festivities of the larger community. These diverse activities build the positive self-image of young people and can also have an important impact on reducing the negative stigma, and even creating a positive public opinion, toward members of the residential youth community. Involving difficult and undisciplined young people in these kinds of activities is not an easy task. However, it can be realized successfully if youth are given the opportunity to experience an atmosphere which enables a genuine “moratorium” (Erickson, 1955). The unique setting of the youth villages has a great potential of creating a "fostering moratorium" for young people living in residential schools, and also for their care takers (Grupper \& Eisikovits, 2000).

\section{The residential care staff}

The issue of residential direct-care workers and the training they require has been the subject of debate among practitioners, decision-makers, and researchers alike (Jones et al., 1986; Grupper, 2002; Romi \& Grupper, 2011; Kobolt \& Deklava, 2008). In many European countries, full professionalization process has occurred, with France taking the lead in the 1960s. A survey on this issue, undertaken by FICE in 1986, resulted in The social pedagogue in Europe: Living with others as a profession (Jones et al., 1986). The very title of this survey suggests the problems of this specific task and the particular way that professionalization has taken shape and progressed. Living together with others as a profession means that there is a way to look at everyday issues - among them nutrition, healthcare, emotional attention, educational support, sports, and storytelling - in a skilled way, not just by using intuition and common sense (Ligthart, 1993). The challenge is to educate residential workers to be "reflective practitioners" (Schon, 1983), while facing a contrasting tendency of seeing such care activities as resembling parental care, which in the eyes of the public does not require professional training.

The point that the neediest children receive services from the most poorly trained workers, who live with them for long and intense hours in unstructured periods of time, 
International Journal of Child, Youth and Family Studies (2013) 2: 224-244

has been highlighted frequently (Shamai \& Moyal-Butwin, 2012). Gottesmann (1987) went so far as to state that a residential direct-care worker is: "The tragic hero of residential education and care” (p. 87). Currently, many countries have moved from the para-professional model toward diverse patterns of professional training for direct-care workers, either in pre-service training in universities or in specialized schools such as the German Fachhochschoole (University for Applied Sciences), or by systematic on-the-job training. In Canada, the University of Victoria opened a special School for Child and Youth Care, and other universities are offering special undergraduate or post-graduate programs in Child and Youth Care (Romi \& Grupper, 2011). The main model locates such workers as general practitioners who have a holistic responsibility toward children in their care and for whom they serve as case managers.

In Israel, great efforts have been made to provide training programs for residential workers, most of them involving on-the-job training. Several academic colleges such as Beit Berl offer undergraduate programs toward a degree in Youth Work, and since 2012 also graduate programs. Some courses are geared specifically for practicing residential care workers, and their work is credited as part of the practicum program. While to date there is no legal requirement to employ only trained personnel, workforce statistics concerning residential direct-care workers show that more than $50 \%$ of new workers nowadays have a university diploma in social science. Policy-makers and directors of schools are working together in order to find ways to empower residential staff and supply them with professional development of competencies and skills that will help them do the job with the students in a successful way.

While professionalization of residential care staff has brought about many positive effects (Kobolt \& Dekleva, 2008), it has also increased dramatically the cost of maintaining a child in residential education or care institutions, resulting in a significant decrease in the number of placements available in many Western countries (Everychild, 2011; Knorth \& Van der Ploeg, 1994; Trede, 2008). In Israel, a careful analysis of the situation has been conducted in order to find the right balance between developing staff members' professionalism while maintaining the cost of residential care at a reasonable level (Grupper, 2003).

\section{New trends in residential education and care}

In Israel, as elsewhere, residential institutions are bound to modify themselves according to broader social changes. The main changes in the Israeli residential network are focused on three major areas:

1. Higher priority to school achievements. Major efforts have been made to guarantee youth in care optimal opportunities to achieve educational success in their schooling, as such success is conceived as a key element in providing better opportunities for them as adults.

2. Involving parents in their children's education. It is now recognized that parents, even the most vulnerable ones, should be treated as full partners in their children's education and care (Klap, 2008). This is not always easy 
International Journal of Child, Youth and Family Studies (2013) 2: 224-244

to achieve in residential establishments that used to operate as closed systems. Today, however, due to the importance attached to the family, there is a major effort for residential staff to incorporate this policy change into everyday life for children in their care.

3. Better collaboration with neighboring communities. Most residential youth villages were established in rural and isolated areas, and the nearby community did not play any role in their functioning. With the overall growth in Israeli population, many of these once isolated villages are now on the outskirts of urban or suburban communities, and interface with their educational and social services. Instead of viewing community-based programs and residential programs as contradictory, they are now thought of as complementary services. New collaborations between residential institutions and communities are gradually being developed, among them new models such as half-way houses and extended day programs that care for children without having to separate them completely from their family and community.

\section{Conclusion}

The residential education and care network in Israel was, and still is, a very important social instrument for coping successfully with complex educational and social challenges. In an immigrant society that is constantly receiving migrant populations from different cultural backgrounds, this is a major challenge. Residential programs have proved to be highly instrumental in achieving successful social integration of immigrant youth (Berry, 2006; Eisikovits, 2008). They have also proven to be an important asset in reintegrating detached youth in high-risk situations. The ethos of community life, practiced in Israeli youth villages, where young people and their educators live together, creates optimal opportunities for developing young people's sense of belonging, first to the inner peer-group circle, later to the youth community, and, hopefully, leading them toward adulthood as people who feel committed and emotionally belonging to their family, community, and to society at large.

Such educational challenges cannot be achieved by educational establishments which are "total institutions" (Goffman, 1962). Following Barnes (1991), we believe that successful group-care programs should function as "greenhouses" rather than "warehouses" and, as such, the Israeli youth village model can be seen as such an empowering vehicle. The "greenhouse" idea implies that in the future, the residential education and care network in Israel and elsewhere, will gain enough public support and sufficient resources in order to empower new generations of multicultural young people. We believe that residential programs should not be seen as the "last resort" but, on the contrary, the preferred option for those who need it and can take best advantage of it. 
International Journal of Child, Youth and Family Studies (2013) 2: 224-244

\section{References}

Al-Haj, M., \& Leshem, E. (2000). Immigrants from the former Soviet Union in Israel: Ten years later. Research report. Haifa: The Center for Multiculturalism and Educational Research, Haifa University.

Anglin, J. P. (2002). Pain, normality, and the struggle for congruence: Reinterpreting residential care for children and youth, Binghamton, NY: Haworth.

Arieli, M., \& Kashti, Y. (1976). Residential settings as social organizations. In Y. Kashti \& M. Arieli (Eds.), Residential settings: Socialization in powerful environments (pp. 9-37). Tel Aviv: Daga (Hebrew).

Arieli, M., Kashti, Y., \& Shlasky, S. (1983). Living at school: Israeli residential schools as people-processing organizations. Tel Aviv: Ramot.

Bardach, R. (2005). Israel: A country of immigration. In World migration 2005: Cost and benefits of international migration. Geneva: International Organization for Migration.

Barnes, H. B. (1991). From warehouse to greenhouse: Play, work and the routines of daily living in groups as the core of the milieu treatment. In J. Beker \& Z. Eisikovits (Eds.), Knowledge utilization in residential child and youth care practice (pp. 123-157). Washington, DC: Child Welfare League of America.

Ben Arie, A., Kosher, H., \& Cohen, S. (2009). Immigrant children in Israel 2009. Jerusalem: National Agency for Children's Wellbeing in collaboration with the Ministry for Immigrant Absorption (Hebrew).

Benbenisty, R., \& Zeira, A. (2008). Assessment of life skills and the needs of adolescents on the verge of leaving care. Mifgash (Encounter: Journal of Social-Educational Work), 28, 17-45 (Hebrew).

Berry, J. W. (2006). Immigrant youth in cultural transition: Acculturation, identity and adaptation across national contexts. Mahwah, NJ: Erlbaum.

Bhatnagar, J. (1981). Multiculturalism and the education of immigrants in Canada. In J. Bhatnagar (Ed.), Educating immigrants (pp. 69-95). London: Croom Helm.

Brendtro, L., Brokenleg, M., \& Van Bockern, S. (1990). Reclaiming youth at risk. Bloomington, IN: National Education Service.

Bronfenbrenner, U. (1970). Two worlds of childhood. New York: Simon \& Schuster.

Bronfenbrenner, U. (1979). The ecology of human development. Cambridge, MA: Harvard University Press. 
International Journal of Child, Youth and Family Studies (2013) 2: 224-244

Davidson-Arad, B. (2010). Four perspectives on the quality of life of children at risk kept at home and removed from home in Israel. British Journal of Social Work, 40(6), 1719-1735.

De Vroom, T., Coenders, M., van Tubergen, F., \& Verkuyten, M. (2011). Economic participation and national self-identification of refugees in the Netherlands. International Migration Review, 45(3), 615-638.

Di Tomasso, L. (2012). More equal than others: The discursive construction of migrant children and families in Canada. International Journal of Child, Youth \& Family Studies, 3(2-3), 331-348.

Eisikovits, R. A. (1995a). An anthropological model for child and youth care worker education. In R. A. Eisikovits (Ed.), The anthropology of child and youth care work (pp. 5-21), New York and London: Haworth.

Eisikovits, R. A. (1995b). Cultural and future perspectives on the residential education alternative. In R. A. Eisikovits, (Ed.), The anthropology of child and youth care work (pp. 67-79). New York and London: Haworth.

Eisikovits, R. A. (2008). Immigrant youth who excel. Charlotte, NC: IAP.

Eisikovits, R. A., \& Beck, R. H. (1990). Models governing the education of new immigrant children in Israel. Comparative Education Review, 34(2), 177-196.

Erickson, E. H. (1955). Ego identity and the psychological moratorium. In H. L. Whitmer \& R. Kotinsky (Eds.), New perspectives for research in juvenile delinquency. Washington, DC: U.S. Department of Health, Education and Welfare.

Eurochild. (2010). Children in alternative care - National surveys. Brussels: Author. http://www.eurochild.org/fileadmin/user_upload

Everychild. (2011). Scaling down: Reducing, reshaping and improving residential care around the world. London: EveryChild Publications, www.everychild.org.uk

Fargues, P. (2011). International migration and the demographic transition: A two-way interaction. International Migration Review, 45(1), 29-67.

Feldman, E. (2007). Russian youth in Israel. In M. Kenigstein (Ed.), The "Russian” faces of Israel: A social portrait (pp. 66-82). Moscow and Jerusalem: Gesharim (Russian). 
International Journal of Child, Youth and Family Studies (2013) 2: 224-244

Frensch, K. M., \& Cameron, G. (2002). Treatment of choice or a last resort? A review of residential placements for children and youth. Child and Youth Care Forum, 31(5), 307-339.

Gibson, M. A. (2001). Immigrant adaptation and patterns of acculturation. Human Development, 44(1), 19-23.

Goffman, E. (1962). Asylums, New York: Anchor.

Gottesmann, M. (1987). Youth aliyah: Continuity and change. Tel Aviv: Cherikover (Hebrew).

Gottesmann, M. (1988). Cultural transition: The case of immigrant youth. Jerusalem: Magnes.

Gottesmann, M. (1991). Residential child care: An international reader. London: Whiting \& Birch with FICE-International.

Greenman, E. (2011). Assimilation choices among immigrant families: Does school context matter? International Migration Review, 44(4), 899-932.

Grupper, E. (2002). Child and youth care work at the cross-roads of the century: From a recognized profession back to an amateur humanitarian mission? In E. J. Knorth, P. M. Van Den Bergh, \& F. Verheij (Eds.), Professionalization and participation in child and youth care (pp. 65-75). Farmham, UK: Ashgate.

Grupper, E. (2003). Economic considerations related to the child and youth care professionalization process: The risks and the challenges. Child and Youth Care Forum, 32(5), 271-281.

Grupper, E. (2008). New challenges for extra-familial care in Israel: Enhancing parental involvement in education. Scottish Journal of Residential Child Care, 7(2), 1426.

Grupper, E., \& Eisikovits, R. A. (2000). "Fostering moratorium” in residential child and youth care education. In Y. Kashti, S. Shlasky, \& M. Arieli (Eds.), Communities of Youth: Studies on Israeli Boarding Schools (pp. 179-197). Tel Aviv: Ramot Tel Aviv University (Hebrew).

Grupper, E., \& Mero-Jaffe, I. (2008). Preserving and rehabilitating family relationships in residential group care. In F. Peters (Ed.), Residential child care and its alternatives (pp. 121-137). Sterling, UK: Trentham Books. 
International Journal of Child, Youth and Family Studies (2013) 2: 224-244

Jockenhovel-Schiecke, H. (1994). Migrant and refugee children in residential care in Germany. In M. Gottesman (Ed.), Recent changes and new trends in extrafamilial child care: An international perspective (pp. 179-182). London: Whiting \& Birch in association with FICE.

Jones, H. D., Courtioux, M., Kalcher, J., Steinhauser, W., Tuggener, H., \& Waldijk, K. (1986). The social pedagogue in Europe: Living with others as a profession. Zurich: FICE-International publications.

Kahan, B. (1994). Review of recent trends in residential and extra-familial care of children and young people. In M. Gottesmann (Ed.), Recent changes and new trends in extra familial child care: An international perspective (pp. 63-68). London: Whiting \& Birch in association with FICE.

Kahane, R. (1986). Informal agencies of socialization and the integration of immigrant youth into society: An example from Israel. International Migration Review, 20 (7), 21-39.

Kahane, R., \& Rapoport, T. (1990). Informal youth movements and the generation of democratic experience: An example from Israel. In O. Ichilov (Ed.), Political socialization, citizenship education and democracy (pp. 221-240). New York: Teachers College Press.

Kashti, Y. (2000). The Israeli youth village: An experiment in training of elite and social integration. In Y. Kashti, S. Slasky, \& M. Arieli (Eds.), Communities of youth: Studies on Israeli boarding schools (pp. 27-46), Tel Aviv: Ramot (Hebrew).

Kashti, Y., Grupper, E., \& Shlasky, S. (2008). Planning residential education in Israel for the next decade (Report for the Ministry of Education). Tel Aviv: Ministry of Education.

Klap, K. (2008). The rehabilitation process for children and the role of the family. In F. Peters (Ed.), Residential child care and its alternatives: International perspectives (pp. 99-121). Stoke-on-Trent, UK: Trentham Books.

Knorth, E. J., \& Van der Ploeg, J. D. (1994). Residential care in the Netherlands and Flanders: Characteristics of admitted children and their family. International Journal of Comparative Family and Marriage, 1, 17-27.

Knorth, E. J., Harder, A. T., Zandberg, T., \& Kendrick, A. J. (2008). Under one roof: A review and selective meta-analysis on the outcomes of residential child and youth care. Children and Youth Services, 30(2), 123-140. 
International Journal of Child, Youth and Family Studies (2013) 2: 224-244

Kobolt, A., \& Dekleva, B. (2008). The professionalization of child and youth care practice: Professionalising social pedagogy - from practice to theory and back to practice. In F. Peters (Ed.), Residential child care and its alternatives: International perspectives (pp. 79-100). Stoke-on-Trent, UK: Trentham Books.

Lambert, R. (1975). The chance of a lifetime. London: Weidenfeld \& Nicolson.

Ligthart, L. E. E. (1993). Care: Its effects and limits. In D. Lane \& E. Amir (Eds.), Training of residential child and youth care staff (pp. 25-42). Jerusalem: Youth Aliyah Publications.

National Council for Children's Wellbeing. (2008). Children living in extra-family care. Children in Israel: Statistical bi-annual review (pp. 95-117). Jerusalem: National Council for Children's Wellbeing (Hebrew).

Peres, Y., \& Lizika, S. (2008). Categories of integration: The case of "Russian immigration” of the 1990s. Megamot (Trends), 55(4), 669-695.

Romi, S., \& Grupper, E. (2011). Training direct youth care workers for fulfilling their task in the social education field. In H. Aharoni (Ed.), Social education in Israel (pp. 312-340). Rehovot: Advance-Publishing House (Hebrew).

Schmid, H. (2006). Report of the public committee designed to investigate the conditions of children and youth at risk and in distress, Jerusalem: Prime Minister Office and Ministry of Social Welfare (Hebrew).

Schmitter-Heisler, B. (2000). The sociology of immigration: From assimilation to segmented integration from the American experience to the global arena. In C. Breltel \& J. Hollifield (Eds.), Migration theory (pp. 77-96). London: Routlege.

Schon, D. (1983). The reflective practitioner. New York: Basic Books.

Shamai, S., \& Moyal-Butwin, M. (2012). "There is a need to create a task-force for preserving residential care workers": Follow up of the adjustment process of residential care workers in their first year of practice. Tel Aviv: Ministry of Education, the Administration for Residential Education and Youth Aliyah (Hebrew).

Shitrit, E. (2006). Acculturation processes and adaptation to studies and society of Ethiopian-born adolescents in religious youth villages. Unpublished doctoral dissertation, Bar-Ilan University, Ramat Gan (Hebrew).

Suarez-Orozco, M. (Ed.). (2007). Learning in a global era: International perspectives on globalization and education (pp. 232-255). Berkeley: University of California Press. 
International Journal of Child, Youth and Family Studies (2013) 2: 224-244

Trede, W. (2008). Residential child care in European countries: Recent trends. In F. Peters (Ed.), Residential child care and its alternatives: International perspectives (pp. 21-33). Stoke-on-Trent, UK: Trentham Books.

Yakhnich, L. (2008). Immigration as a multiple-stressor situation: Stress and coping among immigrants from the former Soviet Union in Israel, International Journal of Stress Management, 15(3), 252-268.

Zeira, A. (2009). Alumni of educational residential settings in Israel: A cultural perspective. Children and Youth Services Review, 31, 1074-1079. 